ailing men? And what reserves of skill and adaptability have the ageing men themselves? In an industry of this kind it becomes difficult to employ an elderly operative or labourer in the production line, unless he has reserves of adaptability to fall back on. This often depended upon whether these partly skilled men have acquired sufficient craft experience to make them still employable at their age. The craft background of many of the older men has given them assurance of employment. Though a good many of them may have been employed for most of their lives on repetitive and machine work, their early training with hand tools would have sufficed to fit them for transferring at some stage to the finishing shop, repairs or jig-making, according to their degree of skill.

Against this, where operatives now in their middle lives have not been trained in craftsmanship but only for machine and assembly operations, in later years they may prove somewhat of a problem. Not only will there probably be large numbers of them ; they will lack the craft training that would have made them adaptable old employees.

Of the furniture industry as a whole, Le Gros Clark suggests that it will still continue to experiment with new techniques and with new and more efficient factory organization. That, inevitably, means concentration and division of labour; and in a factory where the timing of a large number of successive and converging operations is of paramount importance, it becomes difficult to allow too many operatives to fall too far below a standerd level of output. A factory that has incurred heavy overhead charges in the employment of technical and other experts will have streamlined production processes to such an extent that it has to maintain a labour force that is physically capable of the effort and continuity needed. In other words, it has less flexibility than had an old-time workshop in employing its own ailing or ageing operatives.

\title{
FUEL CONSUMPTION AND RESOURCES
}

$\mathrm{O}^{\mathrm{s}}$ $\mathrm{NE}$ of the four main purposes of the Clean $\mathrm{Aix}$ Act is to prohibit in Britain the emission of dark smoke from chimneys, and on February 6 the Minister of Housing and Local Government, Mr. H. Brooke, announeed that from June 1 emission of such smoke will be liable to incur a fine of up to $£ 100$. This will apply to factories, shops, offices and the funnels of ships and railway engines as well as to domestic chimneys, and from that date all new furnaces installed for burning pulverized fuel, or more than one ton an hour of other solid fuels, must be equipped with grit- and dust-arresting plant approved by the local authority.

These regulations will be applied through statutory instrument No. $167(C 2)$ of 1958, which was laid before Parliament on February 6 and appoints June 1 as the day for the operation of all those provisions of the Clean Air Act which were not brought into force by statutory instrument No. $2022(C 19)$ of 1956. It would seem, however, that much still remains to be done in the way of educating both the public and the local authorities on the importance and benefits of smoke control. In replying to a question in a broadcast discussion the following evening, a group of speakers, which included a member of Parliament, showed a regrettable lack of public responsibility and even ignorance of the fact that domestic fires rarely emit dark smoke as defined in the Act- - "as dark as, or darker than, shade two on the Ringelmann chart".

Some reference was made to the importance of smoke abatement in a debate in the House of Lords on February 5. Lord Macdonald of Gwaenysgor, who opened the debate, referred to the importance of the most efficient use of coal and the need for adequate independent scientific advice : he was concerned that this should be available to the Minister of Fuel and Power. Lord Stonehaven, who stressed the value of the National Industrial Fuel Efficiency Service, referred to the savings to be achieved by scrapping the obsolete and inefficient Lancashire boilers still in use, the importance of adequate instrumentation and of competent stokers. Lord de L'Isle insisted that adequate provision for storing fuel is essential if fuel is to be handled economically for central heating systems. Lord Teviot and Lord Hall both referred to the contribution of seience to the efficient use of fuel and power resources, but the major interest of the debate centred in the review of these resources which Lord Mills, the Minister of Power, gave in his reply.

Lord Mills suggested that we are approaching a turning-point in that field. Coal is still the foundation of British fuel economy, but while its consumption has increased by 10 per cent since 1948, that of oil has increased by 91 per cent. There is also a tendency for an increasing proportion of fuel to be consumed in refined forms: since 1948, coke consumption has increased by 15 per cent, gas by 27 per cent and electricity by 99 per cent, so that they now account for 40 per cent or more of inland consumption, compared with 25 per cent before the War. Taking all fuels together, 60 per cent is consumed by industry, 13 per cent by transport and 27 per cent by the domestic consumer. Half our coal supplies go to making fuel or energy, 18 per cent to the domestic consumer, 6 per cent to transport and 26 per cent to industry and commerce, which consumed 60 per cent of electricity supply and more than half that of gas.

Lord Mills said that planning must be based on the assumption that the inland demand for coal will continue to grow, but more slowly than that of other primary fuels. Its direct use by the railways and householders will decrease, but there may be large increases in the demand for coal by coke ovens. As regards small coal, stocks amount to 6 million tons, mainly from deep mines, although two-thirds of open-cast coal is in that form, compared with half of the deep-mined coal. Demand for oil is likely to continue, but the power station oil-conversion programme has been reduced by one-third, to the equivalent of 6 million tons of coal. The advent of nuclear power as a third fuel, however, has brought us to the turning point. Nevertheless, nuclear power at present represents very big demands on capital 
resources and the Minister thought it is entirely right to retard the programme slightly, making up the difference by conventional power stations.

In reply to questions about ZETA, Lord Mills said that while the production of a thermonuclear reaction under controlled conditions has been demonstrated as a practical possibility, the stage reached is comparable with that attained in 1938 when it was first demonstrated that if the atom could be split energy would thereby be released. It took eighteen years to produce the Calder Hall station, which was the prototype of the nuclear power programme, and the problems associated with the controlled release of thermonuclear power are certainly no less formidable. The Government will ensure that full account is taken of all the potentialities opened up by the genius of our scientists and technologists but, even on the most optimistic assumption, it is scarcely conceivable that the present programme for nuclear power will need modification because of these further developments. Lord Mills also suggested that the availability of nuclear power and the removal of the pressure of demand for coal will enable the coal industry to be more selective in its output, both in terms of cost of production and of the kinds of coal produced. He agreed as to the importance of efficiency in consumption and professed himself satisfied with the arrangements for scientific advice. He is setting up a committee to consider improving co-operation between the Area Electricity and Gas Boards, and a pilot plant for underground gasification is under construction.

\section{LIBRARIES}

$\mathrm{E}^{\mathrm{sin}}$ AST met West at the one-day conference of the Scottish Branch of Aslib in the Scottish Central Library, Edinburgh, on February 7. Five speakers representing overseas countries, but all working in Great Britain, gave papers on different aspects of library and information work in Britain and in their own countries.

Miss Margaret Haferd, Librarian of the U.S. Information Service Library in London, spoke of the different useful services that her establishment could offer by way of information on work in America, and technical books.

The principal speaker of the meeting was Dr. J. C. Malloch, of the Scientific Liaison Office of the National Research Council of Canada. His paper was on "Technical Information in the Modern World". $\mathrm{He}$ pointed out how science and technology affect every aspect of daily life, food, clothing, and travel. Even the classicist often does not realize the absurdity of voicing his scorn of science on television and reads Thucydides more easily because a technologist has developed a better printer's ink.

Dr. Malloch suggested that to get the type of general education that is needed, schools and teachers must have available the basic technical information in the right form. He criticized the old dull text teaching Boyle's law, the valency of oxygen or the bones of a frog to students, many of whom will never need this information. He suggested it should be replaced by material which would convey the fascination of scientific discovery and a realization that it really means something to every individual, whatever walk of life they might choose. This is a challenge that cannot be ignored if science is to have the intelligent public support necessary to its development and proper use.

He next spoke about abstracting services, and the tremendous expansion of scientific work in the past twenty years, much of which never appeared in standard journals, and how it had materially altered the situation. While chemists and physicists were served by abstract journals, biologists were badly off. By their own figures, the coverage of Biological Abstracts is only about 40 per cent and the publica. tions of the Commonwealth Agricultural Bureaux cover only special fields, generally selectively. The industrial fields of applied science and engineering are virtually without abstracting services. We are now realizing the vast amount of important scientific and technical information that is available in the U.S.S.R., its satellites and China which is scarcely touched by most of the abstracting services and only available with difficulty in any form.

Scientists need help and this is a suitable task for information services, but one which must be carried out by methods agreeable to the working scientists. Many research organizations now make use of public relations or press officers whose duty it is to make known the activities of the laboratories and to present the results to the general public in an understandable form. Discoveries of science only become of immodiate importance to mankind when they are available for the general benefit. As a result of nearly fifteen years of experience Dr. Malloch believes that the personal approach of field-officers throughout the country is the best method of disseminating information to factories and industry. Dr. Malloch suggested the motto of a public relations officer of the National Research Council in Canada might well be adopted: "No sooner done than said".

Dr. Malloch then went on to describe in detail the work of the National Research Council of Canada. Its library is the major scientific library of Canada and is operated as a national service. It maintains an index of all the translations made of scientific papers in Canada and co-operates with the Commonwealth Index of Translations.

The afternoon session was devoted to papers on library work in their own countries by three ladies at present working in Edinburgh and Aberdeen libraries. Miss L. Somme, of Hammerfest, Norway, at present in Edinburgh, gave the picture of the growth of libraries in her country since the Second World War. Interest in reading had begun during the war when there was little else to do. Now each county had a main district library and attempts were being made to cover outlying districts by mobile libraries by road and sea. The purchasing and binding of books are carried out by the State. Librarians have a three-year course and, as there is a great lack of librarians, positions are easy to obtain.

Miss T. Visser from Utrecht said that in Holland, owing to religious beliefs, it was quite common to find in any one town three public libraries, one neutral, one Roman Catholic and one Calvinistic, 